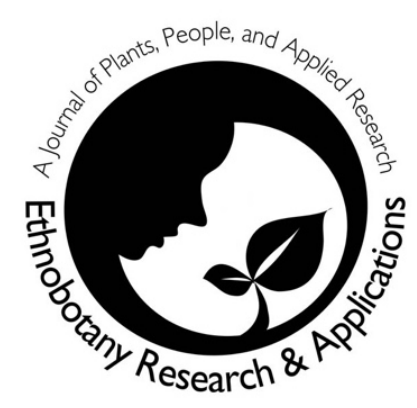

\title{
Brazilian cherry: identifying local knowledge and diversity of Eugenia involucrata in the countryside of Santa Catarina state/Brazil
}

\author{
Julia Goetten Wagner, Karine Louise dos Santos, Dilma \\ Budziak, Rosa Lía Barbieri
}

\section{Research}

\begin{abstract}
Background: Eugenia involucrata (cerejeira do mato) is a fruit species from the Atlantic Forest Biome, which presents several potential uses; however, it is considered an endangered species. An ethnobotanical survey and physical-chemical evaluations were carried out in order to characterize the local knowledge about $E$. involucrata, the variability maintained by local communities and identify fruits with agronomic traits of interest.
\end{abstract}

Methods: The study was conducted in the counties of Curitibanos, Frei Rogério, and Rio das Antas. Ethnographic research was used to gather ethnobotanical knowledge. Fruit samples from seven plants owned by family units were evaluated for diameter, height, $\mathrm{pH}$, vitamin $\mathrm{C}$, titratable acidity, and total soluble solids.

Results: Nineteen family units were interviewed, where eleven use purposes and fifteen agricultural management practices were mentioned for Eugenia involucrata. The main criteria indicated by people interviewed for $E$. involucrata selection were "sweeter fruits," "darker fruits" and "larger fruits.". There was variability among the seven accessions of E. involucrata evaluated. The accessions 3.D, 4.MI, 5.MII and 6.G were the ones that best met the selection criteria. The affective bond, related to familiar or childhood traditions has contributed to the conservation of E. involucrata.

Conclusions: The family units interviewed share a cultural relationship with $E$. involucrata, which has been perpetuated over generations through the continuous use of the species. Among the genetic variability maintained by the family units, the accessions 3.D, 4.MI, 5.MII and 6.G were those which best attend the selection criteria established.

Keywords: cerejeira do Rio Grande, on-farm conservation, ethnobotany. 


\section{Resumo}

Antecedentes. Eugenia involucrata (cerejeira do mato) é uma espécie frutífera da Floresta Atlântica com grande potencial de uso que se encontra atualmente ameaçada de extinção. Foi realizado levantamento etnobotânico e avaliações físico-químicas dos frutos para caracterizar o conhecimento local sobre $E$. involucrata, a variabilidade resguardada pelos mantenedores da espécie e identificar acessos de interesse.

Métodos: O estudo foi conduzido nos municípios de Rio das Antas, Curitibanos e Frei Rogério (SC - Brasil). Levantamento etnobotânico foi realizado para identificar o conhecimento local. As avaliações físico-químicas foram realizadas em amostras de frutos de sete matrizes pertencentes as unidades familiares de Curitibanos e Frei Rogério.

Resultados. Dezenove unidades familiares foram entrevistadas, onde onze usos e quinze métodos de manejo foram mencionados para E. involucrata. Os principais critérios para seleção de cerejeira do mato indicados pelas unidades familiares foram: "frutos doces", "frutos escuros", e "frutos grandes". Houve variabilidade entre os sete acessos de E. involucrata avaliados. Os acessos 3.D, 4.MI, 5.MII e 6.G foram os que melhor atenderam a aos critérios estabelecidos. O vínculo afetivo, relacionado a tradições familiares ou de infância, têm contribuido para a conservação de E. involucrata.

Conclusões. As unidades familiares entrevistadas compartilham um vínculado afetivo com E. involucrata, e esse vínculo tem sido perpetuado geração após geração através do uso continuado da espécie. Entre a variabilidade genética resguardada os acessos 3.D, 4.MI, 5.MII e 6.G foram aqueles que melhor atenderam aos critérios de seleção estabelecidos.

Palavras chave. cerejeira do rio grande, conservação on farm, etnobotânica.

\section{Background}

The threats to biodiversity are increasing, and humanity has a main role in the speed with which the changes in different aspects have been occurring, especially in land use. The anthropogenic disturbances have led to the decline of biodiversity by reducing and isolating forest remnants, ecosystem degradation, irrational exploitation, and negligent resource management (Butzke \& Pontalti 2012, Díaz et al. 2019, Jonsson 2011, Watson et al. 2018).

There are over 300,00 higher species in the world, and from this amount, about 30 thousand correspond to edible species (Barbieri 2003). In this context, Brazil is considered the most important center of the world's biodiversity. Holding six different phytogeographic domains, the country shelters a considerable abundance of species, an expressive presence of endemic species, and greater diversity of tree flora on Earth (Joly et al. 2011, Oliveira et al. 2017, Oliveira et al. 2019). Besides the Amazon domain, which holds great recognition on the international environmental agenda as it is the largest humid tropical forest in the world, also Chaco, Pampa, Cerrado, Caatinga and Atlantic Forest biomes comprise centers of richness and variability of useful species (Oliveira et al. 2019).

Clement et al (2021) point out that Brazil has the most diversified flora of South America, covering 33.161 species, where 6261 are considered "useful" species, with medicinal, food, cultural, or manufacturing purposes. The interaction between ethnic groups, and exchange of interesting plants, has resulted in the overlap of useful species among the biomes, resulting in 4216 plants with historically proven usage in Amazon, 2913 in Atlantic Forest, 2384 in Cerrado, 1463 in Caatinga, 662 in Pampa and 663 in Pantanal. Among the 6261 useful species occurring in Brazil, 1719 are suitable for feeding.

However, despite this scope, the Brazilian food base remains limited to a small number of exotic species (Hunter et al. 2019, Kinupp 2008). This scenario is accentuated by the growing threat of extinction that native species are undergoing since according to the report of Intergovernmental Science-Policy Platform on Biodiversity and Ecosystem Services (IPBES) human activity has led to a threat extinction rate of $25 \%$ among all groups of species analyzed (Díaz et al. 2019). Moreover, it is also relevant to notice the data about the reduction of Brazilian biomes which increases the pressure on native species, where only $81,5 \%$ of the original Amazon domain persists, $44 \%$ of the Cerrado, 42\% of the Caatinga (Buianain et al. 2020; Vilela et al., 2018), and just 12,5\% of the Atlantic Forest (INPE, 2021).

Atlantic Forest had originally 150 million ha (Bergamin et al. 2017), but currently, there is only 16,2 million ha (INPE, 2021), becoming one of the Brazilian biomes most affected by anthropogenic pressure (Bergamin et al. 2017). 
Meanwhile, the Atlantic Forest biome is one of the world's hot spots due to its high sheltered biodiversity and its high rates of endemism (Tabarelli et al. 2005). It holds an extensive history of landscape management by the linguistic families Tupi-Guarani and Macro-Jê, dating back to $\sim 4 \mathrm{k}$ BP where the expansion of Araucaria forests (Araucaria angustifolia) began, as well the use and management of 29 trees species that are often found in remanent areas nowadays (Clement et al., 2021).

Among the species that occur in this overflowing pool of fauna and flora of Atlantic Forest, Eugenia involucrata DC, popularly known as Brazilian cherry, is a fruit tree with several potential uses (Degenhardt et al. 2007). Native from Brazil, E. involucrata is distributed in Uruguay, Paraguay, and Argentina, specifically in Dense Ombrophylous, Seasonal Semidecidual and Mixed Ombrophylous Forest ecosystems. In Brazil, it occurs in the states of Rio de Janeiro, São Paulo, Minas Gerais, Paraná, Santa Catarina, and Rio Grande do Sul, developing preferentially in secondary formations, in level and humid conditions (Lisbôa et al., 2011).

E. involucrata is an evergreen tree species that can reach 15 in height, with a trunk that alternates between graybrown and green colors (Degenhardt et al., 2007). The fruits, called cherries, develop at the tip of the thin branches, with a medium length of 2 to $4 \mathrm{~cm}$, and a diameter between 1,3 and 2,7 cm, showing a black-violaceous coloration. The leaves are glabrous and opposite, measuring 5 to $9 \mathrm{~cm}$ length by 2 to $3 \mathrm{~cm}$ wide, with a dark green and shiny upper side (Lisbôa et al., 2011)

Despite the important role of the fruit trees in food, income generation, supply products and services, most Brazilian species are underutilized or unknown, which led to a market based on exotic species (Degenhardt et al., 2007). This is the case of $E$. involucrata, whose fruits are traditionally used in culinary and for fresh consumption, but there are still no commercial cultivates or structured production chains (Lisbôa et al., 2011). Leaves of E. involucrata are utilized in medicinal infusions, the wood to manufacturing tools, and the plant is found in urban forestry and forest restoration (Lisboa et al., 2011, Lorenzi 2002).

The growth of the productive activities intensified the deforestation of the Atlantic Forest, causing more significant pressure on native species such as $E$. involucrata, which signals the importance of developing public policies to ensure species and ecosystems conservation (Lisbôa et al. 2011, Oliveira 2017). This is the case in the western and Serrana regions of Santa Catarina, a state in southern Brazil, where the historical expansion of logging exploitation, agriculture and livestock had a profound effect on the landscape (Oliveira 2016a, Moretto 2017). Due to the rural exodus being a relatively recent phenomenon in the interior of Santa Catarina, the inland communities own a regional peculiarity, where a rurality character persists even among the urban communities, that maintain a link to the rural environment and share a local identification with the profile of countryside (Oliveira 2016b).

Considering the essential role that communities have in the management, conservation, and expansion of biodiversity their inclusion has been defended as a possible approach to increase the efficiency taxa of conservation efforts (Eyzaguirre \& Iwanaga 1995). At the same time, this bond has a double edge benefit, once that the promotion of native species, sustainable food production systems and resilient ecosystems can assist in the resolution of social demands and problems, like the rural exodus, promoting food security, food sovereignty, even creating an income source for farming families (Alho 2012, Castro \& Devide 2015, Hickey et al. 2016, Hunter et al. 2019).

The development of cultivars can be an effective way to achieve conservation of $E$. involucrata through its use, but for this purpose, it is fundamental to investigate the socioecological context of use, management, and regional preferences for the species (Volpato et al. 2011). In that regard, the ethnobotany, defined as the scientific investigation of the relationship between communities and plants, can be an ally for a holistic comprehension of the process that constitutes the biodiversity panorama, as well as for the design of solutions that go through environmental, social and economic dimensions (Albuquerque et al. 2008, Bussmann 2002; Watson et al. 2018).

Even though many studies cover ecological, functional, and morphological aspects of $E$. involucrata, so far none have focused on traditional or local knowledge about use, management, challenges for conservation, or the identification of criteria selection for the species. Thus, the objective of this work was to identify traditional knowledge of Eugenia involucrata, to verify if there is a difference in the distribution of the knowledge of the interviewed family units related to the place of housing (rural or urban), the municipalities addressed (Curitibanos, Frei Rogério and Rio das Antas, SC/Brazil), and among the composition of family units (male, female, or couple), and also realize the characterization of $E$. involucrata accessions pointed out by the family units. 


\section{Materials and Methods}

\section{Study Area}

The study was conducted from 2015 to 2017 in the Santa Catarina municipalities of Curitibanos, Frei Rogério, and Rio das Antas (Figure 1), in the countryside of Santa Catarina's state (Brazil). Curitibanos and Frei Rogério belong to Serrana mesoregion and show a humid climate, with well-defined seasons, mild summers and are classified as Cfb (Temperate oceanic climate) by Köeppen Climate System (IBGE 2017). Rio das Antas belongs to the western region of Santa Catarina, with a humid subtropical climate characterized by hot summers and no dry season, classified as Cfa by Köeppen Climate System (IBGE 2017).

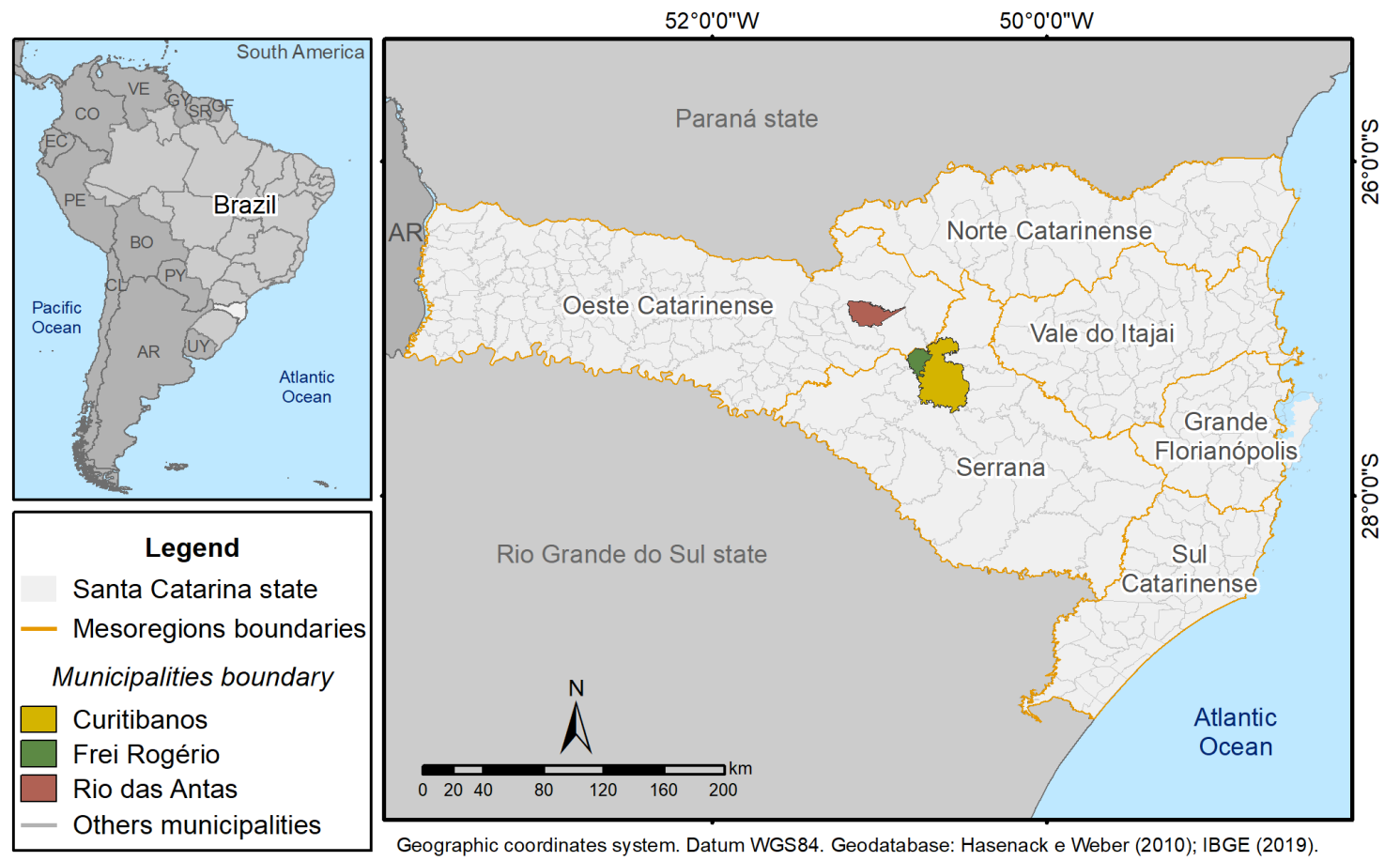

Figure 1. Santa Catarina state and the municipalities of Rio das Antas, Curitibanos and Frei Rogério, coverage area of the study on participatory research with E. involucrata.

\section{Ethnobotanical survey}

The traditional knowledge about the uses of E. involucrata, management activities, morphologic characteristics, perceptions about potentialities, limitations, and parameters of selection for the species, was carried out in the study area through interviews, with the application of semi-structured questionnaires (Viertler 2002). The semistructured questionnaires were applied in rural and urban areas to a sampling unit, in the household level, called "family unit" understood as that family composition that shares the same residence and a bond with the species (Netting 1993). The families interviewed were clustered by similarities based on social context, to verify if there is a difference in knowledge distribution of $E$. involucrata when we consider the different groups: composition of the family units (woman, man, or couple), place of housing (rural or urban), and the municipality of residence (Curitibanos, Frei Rogério, Rio das Antas).

The first study participants were contacted through a partnership locally signed by the Federal University of Santa Catarina (UFSC) and the Santa Catarina Rural Research and Extension Company (EPAGRI). The intentional nonprobabilistic "snowball" technique was employed to increase the sampling (Bailey 1982, Bernard 1994). This strategy consists of optimizing sampling effort, where each participant indicates another possible informant with the attributes targeted in the study (Bailey 1982).

The qualitative data were analyzed through bibliographic review and content analysis (Franco 2005, Minayo 2006), and quantitative data through indices to determine the informant consensus and the nature of knowledge distribution. The calculated indexes were: Informant Diversity Value (IDs), Management Diversity Value (MDs), Use Diversity Value (UDs), and Quality Parameter Diversity Value (QPDs) (adapted from Byg \& Baslev 2001). 
The IDs index measures how many informants mentioned uses/managements/quality parameters for the species and how the information is distributed among the informants. The IDs index was calculated by the formula: IDs = $1 / \sum \mathrm{Pi}^{2}$, where " $\mathrm{Pi}$ " is the contribution of informant "i" to the total knowledge pool of species, " $\mathrm{s}$ " is the number of reports of use/management/quality parameter of the species by the informant " $\mathrm{i}$ " divided by the total number of reports (Byg \& Baslev 2001). The IDs indices of use, management, and selection criteria were calculated separately. The UDs index measures how many use categories a species is used and how it contributes to its total use, with the formula: UDs $=1 / \sum \mathrm{Pc}^{2}$, being " $\mathrm{Pc}$ " contribution to use category " $\mathrm{c}$ " to the total utility of species, and " $\mathrm{s}$ " the number of times the species was mentioned within each use category, divided by the total number of reported uses for the species (Byg \& Baslev 2001).

The indices MDs and QPDs were adapted from UDs index, and respectively measure how many management categories were reported and how evenly these categories contribute to the total number of reports to the management of the species; and how many categories of quality parameter were reported and how these contribute to its total quality parameters. The MDs formula is MDs $=1 / \sum T c^{2}$, where " $T c^{\prime \prime}$ is the contribution to management category " $c$ " to the total management of species, and " $\mathrm{s}$ " is the number of times that one management was mentioned within each management category, divided by the total of management techniques reported (adapted from Byg \& Baslev 2001). The formula used to determinate Quality Parameter Diversity was: QPDs $=1 / \Sigma S c^{2}$, where " $\mathrm{Sc}$ " is the contribution to quality parameter category " $c$ " to the total quality parameters, and " $s$ " is the number of times that one quality parameter was mentioned within each quality parameters category, divided by the total of quality parameters reported (adapted from Byg \& Baslev 2001).

The results of diversity parameters were evaluated in the Genes program (Cruz 2006) through variance analysis $(p \leq 0.05)$, and the statistical tests Kruskal Wallis for more than two categories, and Man-Whitney up to two categories $(p \leq 0.05)$.

\section{Physical-chemical evaluations}

To characterize the fruits of trees owned by the family units and identify those who best meet the quality parameters pointed out in the ethnobotanical survey, the physical-chemical composition of fruits was evaluated. The fruits of accessions indicated by the family units (Figure 2) were collected during the fruiting months of $E$. involucrata (from September to December/2016) in the properties located in the Curitibanos and Frei Rogério - SC region, totaling seven fruit samples, each sample from a different plant considered a treatment.

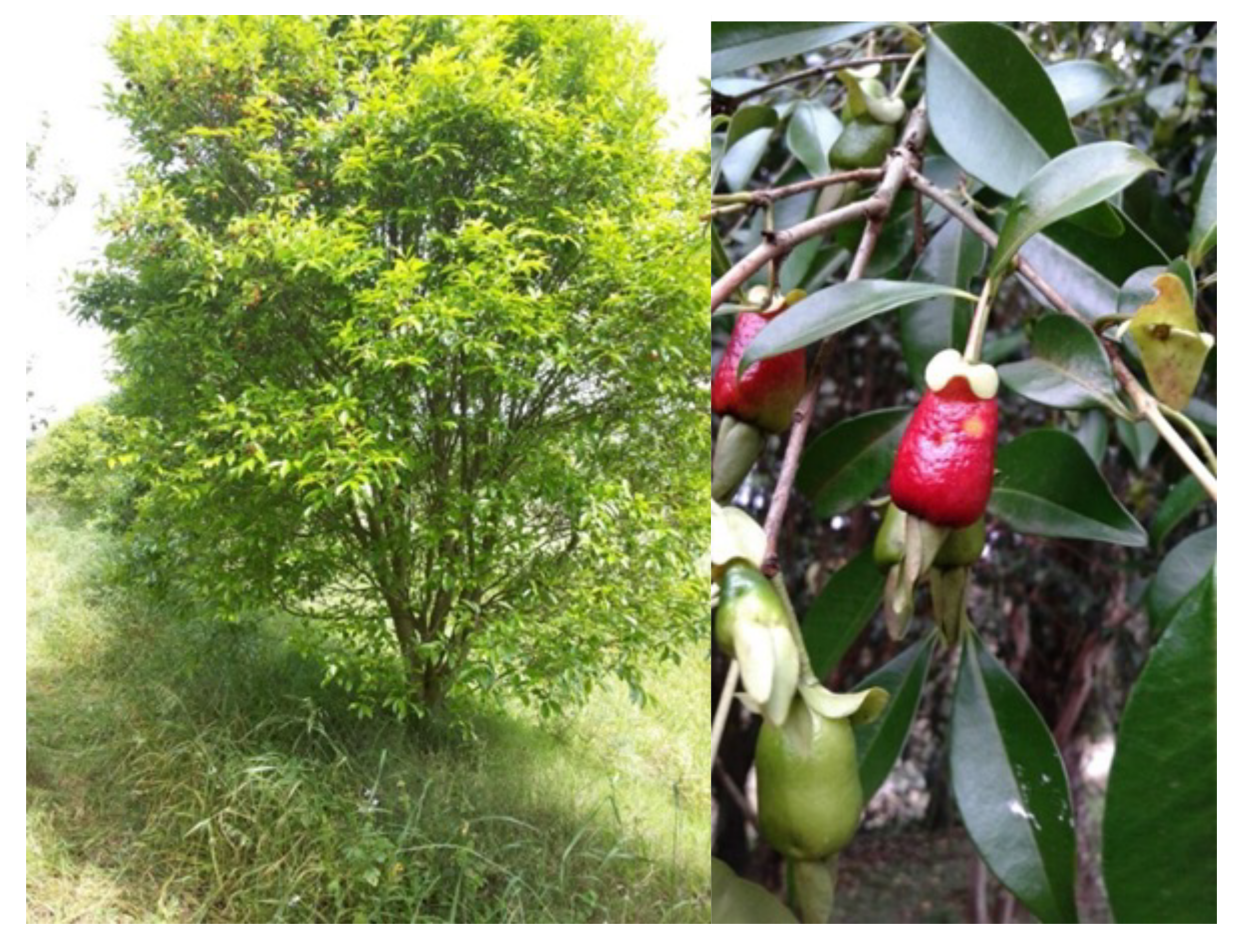

Figure 2. Plant and fruit of Eugenia involucrata (Myrtaceae, common names: Brazilian cherry or Rio Grande cherry). Photo: Julia Goetten Wagner, 2017. 
The evaluation carried out to characterize bromatological differences between the accessions were: determination of the diameter and height of the fruit, the weight of 10 fruits without seed, $\mathrm{pH}$, vitamin $\mathrm{C}$, titratable acidity, and total soluble solids. In addition, the Adolfo Lutz Institute's (2008) recommendations were followed for physicalchemical evaluations. The evaluations were carried out in triplicate in the analytical chemistry laboratory of the Federal University of Santa Catarina - Curitibanos campus.

The diameter and height of the fruits were determined with a digital pachymeter. For fruit weight and pulp yield, an analytical balance was used, and the content of soluble solids was determined using a portable refractometer. The evaluations of diameter, height, weight, and soluble solids were carried out using ten repetitions. The $\mathrm{pH}$ was determined with a pH meter, previously calibrated using $10 \mathrm{~g}$ of the sample diluted in $100 \mathrm{~mL}$ of water. Titratable acidity was measured in the titration method, utilizing phenolphthalein as an indicator, with a $0.1 \mathrm{~N} \mathrm{NaOH}$ standard solution.

The vitamin C content was determined using the official AOAC (Association of Official Analytical Chemists) titrimetric method using the 2-6 dichlorophenol indophenol (DCFI), an indicator reduced by ascorbic acid. The endpoint of titration was detected by turning the solution from colorless to pink when the first drop of DCFI solution was introduced into the system, with all ascorbic acid already consumed.

The results of the physical-chemical evaluations were subjected to analysis of variance $(P>0.05)$ and Tukey's test for the means that differed significantly through the Genes program (Cruz 2008).

\section{Results}

\section{Knowing the maintainers}

Nineteen family units were part of this work, eight units from rural areas and 11 from urban areas. Of the 19 family units, nine live in the municipality of Curitibanos, five in Frei Rogério, and five in Rio das Antas. The familiar occupation among respondents in the rural area was agriculture, and in the urban area, self-employed professionals and professionals linked to the education, services, and public sector participated. From the urban areas 8 family units (out of the 11) share a link with the rural area, having grown up in the countryside, some of them keep a closer relationship with farm activities until these days, where the parents still reside, and family tradition remains. The family units were composed of nine couples, five men and five women.

The average age of the participants was 63 years, ranging from 41 to 83 years. The common point among the eight family units in rural areas was the non-use of chemical inputs in subsistence crops. In the urban area, seven family units maintain biodiverse agroforestry yards, while four family units have only $E$. involucrata in the yard or association with a few species.

\section{Main uses}

Eleven uses were mentioned for E. involucrata, which were classified into six groups: production of candies, drinks, consumption of fresh fruits, tool productions (from the wood), medicinal purposes (of leaves and fruits), and ornamental use. In addition, among the dishes and meals was mentioned using fruits to produce flan, jelly, liquor, and red fruit syrup.

The Use Diversity Value index, representative of the expressiveness of use for a given characteristic, did not assign any difference between the analyzed groups (Table 1), where the different family compositions, municipalities of origin, and place of housing (rural or urban area) did not affect the knowledge distribution for this variable.

However, although no differences were added, there was a greater tendency towards differentiation for fresh consumption (UDs $=0.404$ ) with reported use in all interviews, followed by the category of use for delicatessen production $\left(0.234 \cup D_{S}\right)$, due to the variety of sweet culinary preparations mentioned, and drinks $(0.123)$. In the municipality of Curitibanos, there was a slighter higher tendency for the coefficient of Informant Diversity Value $\left(I_{S}=0.25\right)$ than Frei Rogério $\left(I_{S}=0.183\right)$ and Rio das Antas $\left(I_{S}=0.153\right)$.

All the family units use the species just for subsistence, and the only profitable activity ever observed with $E$. involucrata by the interviewees was the commercialization of seedlings. However, eight family units believe in the potential of the cherry fruits for this purpose, as can be observed in the speech of P.G (M, 83 years old): "-I've never seen it sell, but I think it would come out. Everyone wants novelty, produced with care, good package, it sells". 
The high productivity of $E$. involucrata was reported by family units and interviewee E.A (M, 48 years old) estimates the yield of his plant of $3 \mathrm{~m}$ height at more than $20 \mathrm{~kg}$. Due to the high productivity, processing was commonly mentioned as an alternative use of the fruit, which may have corroborated the diversity of recipes mentioned with the fruit.

Table 1. Number of citations of different use forms of Eugenia involucrata DC, with the statement of Informant Diversity Value $\left(\mathrm{ID}_{\mathrm{S}}\right)$ and Use Diversity Value $\left(\mathrm{UD}_{\mathrm{S}}\right)$ for the various categories of housing place, the composition of the unities interviewed, and the residence municipalities.

\begin{tabular}{|c|c|c|c|c|c|c|c|c|}
\hline \multicolumn{9}{|c|}{ USAGE MENTIONS } \\
\hline Category & Groups & Candies & Drinks & Tools & Medicinal & Ornamental & $\begin{array}{l}\text { In } \\
\text { natura }\end{array}$ & $\begin{array}{l}\text { ID }{ }_{S}^{*} \\
(X \pm S . D .)\end{array}$ \\
\hline \multirow[t]{2}{*}{ House placing } & $\begin{array}{ll}\text { Rural } & \text { area } \\
(n=8) & \end{array}$ & 3 & 3 & 2 & 0 & 2 & 8 & $0.233 \pm 0.08$ \\
\hline & $\begin{array}{l}\text { Urban area } \\
(n=11)\end{array}$ & 8 & 7 & 0 & 1 & 2 & 11 & $0.227 \pm 0.13$ \\
\hline \multirow{3}{*}{$\begin{array}{l}\text { Family Units } \\
\text { Composition }\end{array}$} & Men $(n=5)$ & 1 & 3 & 1 & 1 & 3 & 5 & $0.237 \pm 0.07$ \\
\hline & $\begin{array}{l}\text { Women } \\
(n=5)\end{array}$ & 5 & 4 & 0 & 0 & 0 & 5 & $0.25 \pm 0.23$ \\
\hline & Couple $(n=9)$ & 5 & 3 & 1 & 0 & 1 & 9 & $0.178 \pm 0.06$ \\
\hline \multirow[t]{3}{*}{ Municipalities } & $\begin{array}{l}\text { Curitibanos } \\
(n=9)\end{array}$ & 7 & 7 & 0 & 1 & 2 & 9 & $0.25 \pm 0.16$ \\
\hline & $\begin{array}{l}\text { Frei Rogério } \\
(n=6)\end{array}$ & 2 & 2 & 2 & 0 & 2 & 6 & $0.183 \pm 0.06$ \\
\hline & $\begin{array}{l}\text { Rio das } \\
\text { Antas }(n=4)\end{array}$ & 2 & 1 & 0 & 0 & 0 & 4 & $0.153 \pm 0.08$ \\
\hline Total citations & & 11 & 10 & 2 & 1 & 4 & 19 & - \\
\hline $\mathrm{UD}_{\mathrm{S}}$ & & 0.234 & 0.213 & 0.042 & 0.021 & 0.085 & 0.404 & - \\
\hline
\end{tabular}

$* \mathrm{ID}_{\mathrm{S}}-$ Number of citations from each informant divided by the total number of mentions; $U D_{S}-$ Total number of mentions in the use categories, divided by the total number of citations in all use categories. $X=$ Average; S.D = Standard Deviation.

\section{Agricultural management}

The family units listed nine management techniques. They are pruning height, fertilization in poor soils, cover the plant in frost, thinning, cleaning of the tree surroundings, physical protection of the fruits (bagging of the fruits), use of scarecrow for avoiding animal attacks, use of windbreaks, and remove the bark from the tree (Table 2).

To Management Diversity Value (MDs) index also was not observed a significant difference in the knowledge distribution about the management techniques to $E$. involucrata between evaluated groups. However, differences between the groups may be masked by the small sample universe.

The activities that showed major differentiation tendency were the green manure (MDs $=0.210$ ), cover the plant in frost $(M D s=0.158)$, and prune (MDs $=0.158)$. Although there was no statistical difference for the coefficient Informant Diversity Value, there was a large tendency of differentiation for rural (IDs $=0.1527$ ) compared to urban (IDs = 0.0808), couples showed a higher tendency (IDs=0,1481) than women (IDs = 0.0808) and men (IDs = 0.0666), and it in comparison of the cities Frei Rogério showed the highest value (0.1666). The removal of the barks is done for aesthetic purposes and was mentioned by only one urban family unit. In addition, thinning was another management method cited only for urban family units. Covering the fruits against frost, bagging the fruits, and employ of scarecrows were indicated only by family units from the rural area. These three management methods were mentioned exclusively by couples (and not women and men) and by family units of Frei Rogério (excluding Curitibanos and Rio das Antas), which may explain the sense of differentiation tendency. 
Table 2. Management mentions for Eugenia involucrata DC grouped into different interest categories, with $\mathrm{ID}_{\mathrm{S}}$ (Informant Diversity Value) and $M D_{S}$ (Management Diversity Value) - Curitibanos/2017.

\begin{tabular}{|c|c|c|c|c|c|c|c|c|c|c|c|}
\hline \multicolumn{12}{|c|}{ AGRICULTURAL MANAGEMENT TECHNIQUES MENTIONED } \\
\hline Category & Groups & Fertilization & $\begin{array}{l}\text { Cover against } \\
\text { frost }\end{array}$ & $\begin{array}{l}\text { Bagging } \\
\text { fruits }\end{array}$ & Thinning & $\begin{array}{l}\text { Height } \\
\text { pruning }\end{array}$ & Windbreaks & Scarecrow & $\begin{array}{l}\text { Clean the } \\
\text { ground }\end{array}$ & $\begin{array}{l}\text { Remove } \\
\text { the bark }\end{array}$ & $I_{S}{ }^{a} X \pm S . D$ \\
\hline \multirow[t]{2}{*}{ House placing } & $\begin{array}{l}\text { Rural area } \\
(n=8)\end{array}$ & 3 & 3 & 1 & 0 & 1 & 1 & 1 & 1 & 0 & $0.1527 \pm 0.14$ \\
\hline & $\begin{array}{l}\text { Urban area } \\
(n=11)\end{array}$ & 1 & 0 & 0 & 2 & 2 & 1 & 0 & 1 & 1 & $0.0808 \pm 0.07$ \\
\hline \multirow[t]{3}{*}{$\begin{array}{l}\text { Family Units } \\
\text { Composition }\end{array}$} & $\begin{array}{l}\text { Men } \\
(n=5)\end{array}$ & 0 & 0 & 0 & 0 & 1 & 1 & 1 & 0 & 0 & $0.0666 \pm 0.06$ \\
\hline & $\begin{array}{l}\text { Women } \\
(n=5)\end{array}$ & 0 & 0 & 0 & 1 & 1 & 0 & 0 & 1 & 1 & $0.0888 \pm 0.09$ \\
\hline & $\begin{array}{l}\text { Couple } \\
(n=9)\end{array}$ & 4 & 3 & 1 & 1 & 1 & 1 & 0 & 1 & 0 & $0.1481 \pm 0.13$ \\
\hline \multirow[t]{3}{*}{ Municipalities } & $\begin{array}{l}\text { Curitibanos } \\
(n=9)\end{array}$ & 1 & 0 & 0 & 2 & 2 & 1 & 0 & 0 & 0 & $0.0617 \pm 0,16$ \\
\hline & $\begin{array}{l}\text { Frei Rogério } \\
(n=6)\end{array}$ & 3 & 3 & 1 & 0 & 1 & 1 & 1 & 0 & 0 & $0.1666 \pm 0.05$ \\
\hline & $\begin{array}{l}\text { Rio das Antas } \\
(n=4)\end{array}$ & 1 & 0 & 0 & 0 & 0 & 0 & 0 & 1 & 1 & $0.055 \pm 0.11$ \\
\hline Total citations & & 4 & 3 & 1 & 2 & 3 & 2 & 1 & 2 & 1 & - \\
\hline $\mathrm{MD}_{\mathrm{s}}$ & & 0.210 & 0.158 & 0.053 & 0.105 & 0.158 & 0.105 & 0.057 & 0.105 & 0.053 & - \\
\hline
\end{tabular}

${ }^{a} D_{S}-$ Number of citations of each informant divided by the total number of citations; $M D_{S}-$ Total number of citations for the category, divided by the total number of citations in all categories. $X=$ Average; Standard Deviation. 
Fertilization was the management technique that showed greater consensus, however, in general, the family units believe that the species can develop even in poor soils. Although nine techniques have been mentioned, seven family units believe that no special care or management is needed for the plants, they also defend that $E$. involucrata is very hardy and disease resistant. Twelve family units mentioned the visitation of birds and other animals to plants, like insects, bats, coati (Nasua nasua), giant anteater (Myrmecophaga tridactyla), and even farm animals. In two cases, this situation was treated as a problem, which was solved by the use of scarecrow by one family unit, or fruit bagging by other. But the others ten family units considered the visits a pleasant surprise, especially the visitation of birds. From the sample of 19 family units, 12 made mentions about birds in different aspects, even though there was no specific topic about this group of animals. One remarkable mention about birds was made by N.O (W, 71 years) who affirms that she likes to have $E$. involucrata at home because the tree attracts the birds "-I like to wake up with the bird's songs", an aspect that was also mentioned by P.G (M, 83 years).

Height pruning was considered important to facilitate the harvest since the plants can get too tall. About this issue the interviewed N.O (W, 71 years old) explains that: "-We do the harvest with a stick, beating, but it hurts the plant a lot, not to mention that unripe fruits fall, leaving few for the birds.

Between the rural area, couples interviewed there was a predominant division of labor, where men focus on agricultural production, and women work on housekeeping, child-rearing, subsistence cropping, and eventually help in agricultural production for sale. Despite the division of labor, both mentioned management techniques for E. involucrata, even men who are not attached with subsistence cropping

\section{Quality Parameters}

In defining the quality parameters according to which $E$. involucrata must be considered an "ideal" plant, 15 criteria were pointed out to select the plants of interest (Table 3). But, again, there was no difference in determining the selection parameters between the different groups analyzed, in a way that the sweet taste of the fruits, the primary selection criterion pointed out, was heterogeneous among the family units, representing 18 of 19 family units.

After the "sweeter fruits" criterion, with a QPDs of 0.339, "darker fruits" was the second most mentioned criterion, with QPDs $=0.125$. A measure that is also linked to the flavor of the fruit since the intensity of the coloring is connected to the point maturation. Other parameters for $E$. involucrata selection related to fruit quality were: larger, liquid, juicy, and healthy fruits. They were also pointed out as selection criteria: high productivity, healthy seedlings, and more diminutive plant stature to facilitate the harvest.

When asked if might be potential for selling $E$. involucrata fruits the preference for larger fruits was raised: "-I've never seen it sold, but if it's well cared, a very big one, it can be sold" A.R.P (M, 64 years old).

The preference for organic fruits was mentioned by three family units, one from the urban area, and two from the rural area, and about this, it is noticeable that even in these two perspectives, one from consumer and the other from a farmer, that there is a concern with the origin and quality of the products. This issue is highlighted when we consider that all rural family units produce organics for the household level, even those that employ the traditional system of producing for sale, which is significant.

Only one family unit pointed out "flowering in spring" as a selection criterion, this is justified by the occurrence of abnormal blooms when the phenological cycle is shortened leading to reduced yield or fruit abortion. The health of the fruit was pointed as a selection criterion by three family units that observed plagues and diseases in plants of $E$, involucrata that affect the yield, like rust, borer, and caterpillar.

Three family units stated that there is a difference in the taste of $E$. involucrata fruits linked to shape, the elongated fruits are sweeter and have more pulp than the round ones. Nevertheless, there was no mention of preferred fruit shapes in the criteria selection definition, showing that what is considered is the sweetness of the fruits. 


\section{Ethnobotany Research and Applications}

Table 3. Quality parameters of plants and fruits of Eugenia involucrata DC defined by the participants, with ID (Informant Diversity Value) and QPD $_{S}($ Parameter Diversity Value). Curitibanos/2017.

\begin{tabular}{|c|c|c|c|c|c|c|c|c|c|c|c|c|c|c|c|c|c|}
\hline \multicolumn{18}{|c|}{ QUALITY PARAMETERS MENTIONED } \\
\hline $\begin{array}{l}\text { Category } \\
\text { Groups }\end{array}$ & & $\begin{array}{l}\text { High } \\
\text { production }\end{array}$ & $\begin{array}{l}\text { Larger } \\
\text { fruits }\end{array}$ & $\begin{array}{l}\text { Sweeter } \\
\text { fruits }\end{array}$ & $\begin{array}{l}\text { Acidic } \\
\text { fruits for } \\
\text { jelly }\end{array}$ & $\begin{array}{l}\text { Ripe } \\
\text { fruits }\end{array}$ & $\begin{array}{l}\text { Healthy } \\
\text { fruits }\end{array}$ & $\begin{array}{l}\text { Healthy } \\
\text { seedling }\end{array}$ & $\begin{array}{l}\text { Tree } \\
\text { smaller } \\
\text { size }\end{array}$ & $\begin{array}{l}\text { Flowering } \\
\text { in spring }\end{array}$ & $\begin{array}{l}\text { Red } \\
\text { fruits }\end{array}$ & $\begin{array}{l}\text { Darker } \\
\text { fruit }\end{array}$ & Juicy & $\begin{array}{l}\text { More } \\
\text { pulp }\end{array}$ & Organic & $\begin{array}{l}\text { Good } \\
\text { wood }\end{array}$ & $\begin{array}{l}I_{S}{ }^{a} \\
(X \pm S . D \\
.)\end{array}$ \\
\hline \multirow[t]{2}{*}{ House Placing } & $\begin{array}{l}\text { Rural area } \\
(n=8)\end{array}$ & 1 & 1 & 8 & 0 & 1 & 2 & 2 & 1 & 0 & 0 & 3 & 1 & 1 & 1 & 2 & $\begin{array}{l}0.2 \\
\pm 0.09\end{array}$ \\
\hline & $\begin{array}{l}\text { Urban area } \\
(n=11)\end{array}$ & 1 & 4 & 11 & 1 & 3 & 1 & 0 & 2 & 1 & 1 & 4 & 1 & 0 & 2 & 0 & $\begin{array}{l}0.1818 \\
\pm 0.08\end{array}$ \\
\hline \multirow[t]{3}{*}{$\begin{array}{l}\text { Family Units } \\
\text { Composition }\end{array}$} & $\begin{array}{l}\text { Men } \\
(n=5)\end{array}$ & 1 & 1 & 5 & 1 & 0 & 1 & 0 & 1 & 1 & 0 & 0 & 0 & 0 & 1 & 1 & $\begin{array}{l}0.16 \\
\pm 0.05\end{array}$ \\
\hline & $\begin{array}{l}\text { Women } \\
(n=5)\end{array}$ & 0 & 2 & 5 & 0 & 2 & 0 & 0 & 1 & 0 & 1 & 2 & 1 & 0 & 1 & 0 & $\begin{array}{l}0.2 \\
\pm 0.11\end{array}$ \\
\hline & $\begin{array}{l}\text { Casal } \\
(\mathrm{n}=9)\end{array}$ & 1 & 2 & 9 & 0 & 2 & 2 & 2 & 1 & 0 & 0 & 5 & 1 & 1 & 1 & 1 & $\begin{array}{l}0.2 \\
\pm 0.08\end{array}$ \\
\hline \multirow[t]{3}{*}{ Municipalities } & $\begin{array}{l}\text { Curitibanos } \\
(n=9)\end{array}$ & 1 & 3 & 9 & 1 & 2 & 1 & 0 & 1 & 1 & 0 & 3 & 1 & 0 & 1 & 0 & $\begin{array}{l}0.1629 \\
\pm 0.04\end{array}$ \\
\hline & $\begin{array}{l}\text { Frei Rogério } \\
(n=6)\end{array}$ & 1 & 1 & 6 & 0 & 1 & 2 & 2 & 0 & 0 & 0 & 2 & 0 & 0 & 1 & 2 & $\begin{array}{l}0.2 \\
\pm 0.10\end{array}$ \\
\hline & $\begin{array}{l}\text { Rio das } \\
\text { Antas }(n=4)\end{array}$ & 0 & 1 & 4 & 0 & 1 & 0 & 0 & 2 & 0 & 1 & 2 & 1 & 1 & 1 & 0 & $\begin{array}{l}0.23 \\
\pm 0.12\end{array}$ \\
\hline Total citations & & 2 & 5 & 19 & 1 & 4 & 3 & 2 & 3 & 1 & 1 & 7 & 2 & 1 & 3 & 2 & \\
\hline $\mathrm{QPD}_{\mathrm{S}}$ & & 0.036 & 0.089 & 0.339 & 0.017 & 0.071 & 0.053 & 0.036 & 0.053 & 0.017 & 0.017 & 0.125 & 0.036 & 0.017 & 0.053 & 0.036 & \\
\hline
\end{tabular}

${ }^{a D_{S}}$ - Number of citations of each informant divided by the total number of citations; $Q_{P D}-$ Total number of citations for the category, divided by the total number of citations in all categories. $\mathrm{X}=$ Average; $\mathrm{S} . \mathrm{D}=$ Standard deviation 


\section{Identifying relationship between family units and $E$. involucrata}

Fifty plants of $E$. involucrata were identified in possession of the family units; 33 of them are in rural areas, and 17 plants are in urban areas. Of 29 plants owned by urban family units, 12 are located in the family farms of these units. The matrice's age ranged from 3 years to more than 70, and most of the plants addressed in the study were planted by the family units. Of the total (19) of family units in 14 cases the species did not occur spontaneously, these 14 family units planted 37, and only 13 plants occurred naturally in the landscape, so there is an apparent effort to cultivate and conserve the species.

The flowering event was described between September and October, and the fruiting between September until December for 15 family units, however, two family units indicate the flowering in August, one in July and one family unit did not know the exact period.

Ten family units perceive the variation in production associated with biotic and abiotic factors, such as reduced yields caused by the absence of bees for pollination, frosts and excessive rainfall in the flowering period which leading to flower abortion or early flower drop, low temperatures causing the flower and fruit death, while higher temperatures increase the fruit yield. The importance of bees for pollination was emphasized in O.P.R (M, 62 years old) statement: "-The production varies from one year to the next when there is a lot of bees the tree is loaded with fruits, and the wind also helps". Among these, four family units report that the undefined winter anticipates the flowering events, and that condition caused reduced yields in the year 2015. However, the other nine family units don't perceive yield variation and claim that year after year production remains higher than house level consumption, so that processing is a strategy employed to maximize the use of fruits.

Within the sample universe of 19 family units, the bond origin with the species for 15 originates from the family nucleus. In 11 cases this connection with the species was established in childhood. In addition, the family influence is still felt today since, considering the plants currently sheltered by the family units, in five cases, a family member donated or planted the seedlings. Furthermore the "family component" not only remains at the origin of the bond with $E$. involucrata but is also perpetuated through generations by cultural transmission. This bond is kept evergreen as seen in this study where 15 family units have sons, and 11 have grandsons, and the contact with the species has been promoted by the elders.

Among all interviewees, only three family units reported having the first contact with $E$. involucrata after adulthood. In three family units formed by couples, just the husband knew E. involucrata since childhood, and due to sentimental value associated with the species, they took their wives to meet the cherry tree that they knew as children.

The relationship between family and childhood as basis of sentimental value associated with the species can be perceived in I.L's statements (W, 67 years old): "-We used to eat ( $E$. involucrata) as a child when we are about five years old, there were in the countryside close to home, I went with my brother, my father looked for it," and also in the speech of DF (W, 75 years old) "-Since I was a child I know, I took it from a neighbor after school [...] My Family also ate.". The effort to reestablish the nostalgic link by cultivating $E$. involucrata is perceptible in M. F (W, 45 years old) speech: "-I like to cultivate different things, reminiscent of childhood."

The finding that there is a predominant link between family and childhood with the species, plus the fact that the participants cultivated the vast majority of plants investigated in the study, highlights the vital role that traditional and local communities have in conservation processes. At the same time, they renew the traditions that permeate the use of the species.

\section{Conservation scenario: status and challenges}

Motivators for conservation were investigated in the survey, and the usefulness of the fruits, seeds, bark, and wood were the most common reasons for cultivating and keeping $E$. involucrata, being mentioned by 11 family units. The environmental concern was the second more often motivator for conservation, pointed out by six family units, as can be seen in the speech of GS (F, 72 years old): "-We have to take care of what is ours, it is important to preserve it for the youth, the next generation, to also be able to know about it".

Nutraceutical characteristics of $E$. involucrata's fruits, related with health benefits, were mentioned by two family units as a promoter for conservation: "-Makes the intestines work, is good for health" (S.G - W, 57 years old); "Because of my mom I like the native (fruits), she has diabetes and fruits are good for health" (Y.G - W, 49). Curiosity 
was the main motivator for two family units that did not know the species before cultivating it, and one noteworthy line was from an urban area woman interviewed who said "I didn't know the cherry tree, but I have it because we have in our blood the habit of cultivating" (J.G - W, 52 years old). At last, the ornamental potential was also mentioned as a promoter of conservation by a family unit.

The perceptions about the occurrence of $E$. involucrata over time were heterogeneous. Ten family units do not know if the frequency of the plants in the landscape has changed, four family units attest that the number of remnants has decreased, three family units say that there has always been few in the Curitibanos region as defended by D.G (M, 75 years old) "Here in the region never had much ( $E$. involucrata trees), but there, in Rio das Antas, always been much more", and two family units believe that the frequency has increased.

The four family units that talked about the reduction of $E$. involucrata over time demonstrate a perception of the context of the fragility of native species in general. In this sense, the speech of P. G (W, 83 years old) stands out, who says that the world has been moving towards the development of environmental awareness: "It's getting better... Today people are more aware of preserving nature, a while ago they looked like they were enemies of the forest". The maintainer G. S (72 years old) associates this detachment and confinement with the technological way of life that we have developed: "-Young people do not go further, because of modernity, they spend the whole day fiddling with their cell phones. There had to be government's incentive to the young get to know the plants in the field." Also, two family units showed concern about the low regeneration of the species, due to the absence of new plants coming up where the seeds fall.

To promote appreciation of E. involucrata, several ideas were pointed out by the family units. Disclosure is considered the most effective way, especially with a focus on children, as proposed by M.M.F (M, 80 years old): "The older people like it, young people lack publicity, in schools, to take children during the flowering season," and N. O (W, 71 years old): "-You have to raise awareness, you know, it is hard work, but it comes from culture, from children, where it is being formed.". The disclosure ideas include lectures, talks, and the use of audiovisual tools. The dissemination of productive aspects aiming income generation was also mentioned by three family units: J. M. $Y(W, 55$ years old $)$ "-I think that a way to increase the appreciation would be the disclosure of technical aspects to the producers, production capacity, commercialization and industrialization, the producers than would look for more". Other ideas for promotion were public policies to establish street names with the name of native species, donation of seedlings in commemorative dates, employing fruit trees in parks, and stimulating native fruit consumption in schools.

The donation of seedlings was one of the suggestions for the species promotion, but three family units already act in this direction by giving plants of $E$. involucrata friends and family. These seedlings are produced from the seeds of the consumed fruits, in garden beds.

\section{Physical-chemical evaluations}

Significant differences were observed between the accessions regarding the parameters of height and fruit diameter, $\mathrm{pH}$, titratable acidity, and SS/AT ratio (Table 4). The accessions 3.D, 4.MI, 5.MII, and 6.G had the highest averages for height and fruit diameter. The concentration of $C$ vitamin in $100 \mathrm{~mL}$ of juice varied from $28.70 \mathrm{mg} / \mathrm{mL}$ (accession 7.E) to $60.81 \mathrm{mg}$ of ascorbic acid in $100 \mathrm{~mL}$ of juice (accession 1.R). Soluble solids expressed in degrees Brix ranged from 5.6 to 10.6 .

Table 4: Results of physical-chemical evaluations of seven accessions of Eugenia involucrata DC from Curitibanos and Frei Rogério (SC/Brazil) municipalities in December 2017.

\begin{tabular}{lllllllll}
\hline Parameters & \multicolumn{2}{l}{ Samples* } & & & & \\
& 1. R & 2.C & 3.D & 4.MI & 5.MII & 6.G & 7.E & Average \\
\hline Height $(\mathrm{cm})$ & $2.23 \mathrm{~b}$ & $2.15 \mathrm{~b}$ & $2.60 \mathrm{a}$ & $2.53 \mathrm{a}$ & $2.64 \mathrm{a}$ & $2.65 \mathrm{a}$ & $2.35 \mathrm{ab}$ & 2.45 \\
\hline Diameter(cm) & $1.36 \mathrm{~b}$ & $\begin{array}{l}1.63 \mathrm{a} \\
\mathrm{b}\end{array}$ & $1.96 \mathrm{a}$ & $1.95 \mathrm{a}$ & $2.08 \mathrm{a}$ & $1.94 \mathrm{a}$ & $1.42 \mathrm{~b}$ & 1.762 \\
\hline${ }^{\circ}$ Brix & 7.8 & 5.6 & 10.6 & 7.6 & 6.3 & 6.8 & 6.8 & 7.357 \\
\hline
\end{tabular}




\begin{tabular}{|c|c|c|c|c|c|c|c|c|}
\hline $\begin{array}{ll}\text { C } & \text { vitamin }^{1} \\
(\mathrm{mg}) & \end{array}$ & $60.81 a$ & $52.2 a$ & $72.47 a$ & $50.13 a$ & $61.87 a$ & $46.9 a$ & $28.70 a$ & 53.297 \\
\hline $\mathrm{pH}$ & $3.9 b c$ & $3.7 c d$ & $4.3 a$ & $3.6 \mathrm{~d}$ & $4.1 a b$ & $3.7 \mathrm{~cd}$ & $3.4 \mathrm{e}$ & 3.814 \\
\hline $\begin{array}{l}\text { Wight of } 10 \\
\text { fruits }(\mathrm{g})\end{array}$ & 38.28 & 37.36 & 60.28 & 55.16 & 59.61 & 58.17 & 37.51 & 49.481 \\
\hline $\begin{array}{l}\text { Wight of } 10 \\
\text { pitted fruits }(\mathrm{g})\end{array}$ & 19.56 & 26.92 & 45.22 & 35.84 & 38.39 & 43.14 & 25.96 & 33.575 \\
\hline $\begin{array}{l}\text { Titratable acid } \\
\text { (\%) }\end{array}$ & $0.5 e$ & $0.6 \mathrm{~cd}$ & $1.4 a$ & $0.7 c$ & $0.9 b$ & $0.3 f$ & $0.6 \mathrm{~d}$ & 0.714 \\
\hline Ratio (SS/AT) & $15.6 b$ & $9.33 d$ & $7.57 e$ & $10.85 c$ & $7.00 \mathrm{e}$ & $22.66 a$ & $11.33 c$ & 12.048 \\
\hline \multicolumn{9}{|c|}{ * The samples were characterized by the owner's initials } \\
\hline \multicolumn{9}{|c|}{$\begin{array}{l}{ }^{1} \mathrm{mg} \text { of ascorbic acid in } 100 \mathrm{~mL} \text { of juice } \\
\text { 2Same letters on the line indicate no statistical difference. Different letters point to the significant } \\
\text { difference between the data. }\end{array}$} \\
\hline
\end{tabular}

The accessions 3.D and M.II had the highest $\mathrm{pH}$ values: 4.3 and 4.1, respectively, and 7.E, with 3.4, had the lowest value. The weight of the fruits varied from $38 \mathrm{~g}$ to $60.28 \mathrm{~g}$. The accession $6 . \mathrm{G}$ had the lowest titratable acidity value and had the highest SS/AT ratio.

\section{Discussion}

\section{Mutual reinforcement between cultural diversity and biological diversity}

Although in many conceptions humanity has been coined in an ontological domain external to the natural system, history demonstrates a positive relationship between the practices of traditional communities and diversification of biodiversity (Berkes et al. 1994, Descola 1999, UNESCO 2003). There is a relation between cultural and biological diversity to reinforce each other, as plants are inserted in cultural diversity in communities, associated with social behaviors, practices, symbolism, and religious meanings (Gomes et al. 2014, Toledo 1988).

The study of the social nature of food explores the relationship between the choice of foods and the cultural and social aspects that permeate them. The preference for certain foods is strongly associated with the group's identity and the socio-cultural context (Lima et al. 2015). In a more profound sense, the act of eating carries an intimate relationship between the body and food since such action is so strongly related to our survival (Mintz 2001).

When investigating what force motivates the conservation of $E$. involucrata for the family units of the study, it was possible to observe that the predominant patterns are related to the functionality of the species, environmental concern, curiosity, and utility. Health benefits of the consumption of $E$. involucrata's fruits promoted the cultivation of the species by family units. In the last years, advances were made in the characterization of the nutraceutical aspects in different parts of the plant. Antioxidant activity was found in leaves, fruits, and seeds of $E$. involucrata (Nicácio et al. 2017) and the leaf extract has shown digestive, antibacterial, painkiller, antinociceptive, and antitumor activities (Dametto 2014, Nicácio et al. 2017, Sardi et al. 2017; Vechi et al., 2018; Girardelo et al., 2020). One interviewee mentioned the benefits of fruit for diabetes control. Although there is no study showing inhibition activity of $E$. involucrata fruits in carbohydrates catabolism, Cipriani et al. (2020) reported enzymatic inhibition of $\alpha$-glucosidase by the leaf extracts. The activity of enzymatic inhibition slows down the absorption of carbohydrates and suppresses postprandial hyperglycemia, a useful attribute in the control of diabetes mellitus, a disease characterized by chronic hyperglycemia.

Besides the functional bias which motivates the conservation of $E$. involucrata, in this study was noted that the maintenance of the species is related to deeper connections, like familiar traditions and bonds established in childhood. Of the total of 50 plants addressed in the ethnobotanical survey, 37 did not occur naturally in the landscape but were planted by the family units. This issue signals an apparent effort to perpetuate the cultural relationship associated with the family units and consumption of this relationship, for 15 of 19 family units, has its roots in childhood and is strengthened in family tradition. These relationships are defended by Joly et al. (2011) and Eyzaguirre \& Iwanaga (1995) as allied in the fight against environmental threats because the communities have an essential role in agricultural biodiversity, contributing to its creation, maintenance, and protection. 


\section{Conservation through use: to value it is necessary to know}

Although family units share an interest in native species, the common perception is that the world, in general, does not seem to be receptive to this issue. An interview mentioned the influence of the highly technological era that we are living in as a cause of detachment from nature. The cultural imbalance caused by the distance between humanity and nature has led to a status of "nature-deficit disorder" according to the determination of the researcher Richard Louv (2009). A 2014 study published by the agency "We Are Social" showed that in Brazil, the average daily time spent on the internet was 5 hours and 26 minutes (We are social, HOOTSUITETM 2017). Several social pathologies can be linked to the alienation of nature, such as obesity, attention deficit, and physical illnesses. Contact with nature seems to have beneficial impacts even on school performance. Designers pay attention to establishing green areas in public and private spaces since the contact with of the environment seems to confer those beneficial impacts (Louv 2009).

The focus on children to consolidate the sense of care and affection with $E$. involucrata in the next generation was one of the most often ideas appointed to increase the species appreciation. One idea to sensitize the children was the promotion of school trips to see E. involucrata blooming. This approach can be defended since sensory experimentation is an effective way to awaken environmental awareness, as this contact allows emotional connections to be established and transformations in the way children see and treat the natural world (Abrão 2016, Milach \& Louzada 2016). Initial experiences in recognizing the texture and functions of nature should be promoted to develop children's perception of care (Tunnicliffe 2001).

Another idea pointed out by family units to increase the interest in E. involucrata and promote its conservation was the disclosure of management techniques and productive aspects. This issue underlines the important role of use for conservation: the maintenance of what is valuable is recommended, in agreement with the idea that income generation is a perspective that can contribute to the scenario of conservation (Negi et al. 2017, Stella \& Kageyama, 2006).

The International Plant Genetic Resources Institute (IPGR) sees the promotion of underutilized crops species (NUS) as part of the solution to achieving food security and nutrition as well as conservation. Conservation through use is the heart of the IRGR strategy for safeguarding NUS (Padulosi et al. 1999, Cowling et al 1998). The principal constraints in a report of IRGR for underutilized species were the low competitiveness, scarce knowledge of use forms and research of genetic diversity, loss of traditional knowledge, lack of propagation techniques, low income, lack of markets, lack of attractive traits, insufficient knowledge on cultural traits and factors linked with policies. In this regard, this study contributes to fulfilling the gaps to identify use forms, genetic diversity, the preferred traits, and to register local knowledge that could be lost.

Nine management techniques were mentioned for the species. The removal of the barks was mentioned by one family unit, but what makes this interesting is that character of "debarking" of the tree is evoked by Tupi nomenclature for E. involucrata. "barapiroca" which means "fruit of the tree that loses its barks" (Gonçalves $\&$ Guazelli 2014).

Fertilization was the management technique most mentioned, but even so, the family units believe that $E$. involucrata is not very demanding in soil nutrition. This statement agrees with Lisbôa et al (2011) who pointed out that even if the ideal soil condition is drained, deep and rich in organic matter, the species can persist in poor soils.

The visitation of several animals emphasizes the role of the species in different ecological relationships, feeding animals, harboring others, and also being highly suitable to employ in restoration programs due to the interest of avifauna (Carvalho 2009, Rego et al. 2006).

The main criteria pointed by family units to $E$. involucrata selection were: sweeter fruits, darker fruits, and larger fruits. The preference for sweeter fruits can be expected since the most common form of use of $E$. involucrata was consumption in natura. Traditionally, the sweetness of the fruits is a characteristic sought by the Brazilian consumer for several fruit species (Cruz et al. 2019, Fortaleza et al. 2005, Schiassi et al. 2018, Hansen et al. 2008, Penso et al. 2018). The only maintainer who did not point to "sweeter fruits" as a dominant criterion of selection specified the interest in sweeter fruits as an aptitude for fresh fruit trade. In comparison, more acidic fruits would be more suitable if they were intended for industrialization in jelly production. Furthermore, the intensity of coloring, the second most frequently mentioned selection criteria, can be associated with maturation and directly related to sweet flavor, 
due to the correlation between the concentration of anthocyanins and the concentration of sugars (Palonen $\&$ Weber 2019).

\section{Physical-chemical variability}

Characterizing existing diversity is essential to stimulate species' use and conservation. Even in a small sample analyzed in this study was possible to identify variability managed and protected by family units, with agronomics characteristic of interest. There was a statistical difference for height, diameter, $\mathrm{pH}$, vitamin $\mathrm{C}$, titratable acid, and ratio in the accession of Curitibanos and Frei Rogério. The height of the fruits exceeded the diameter in all samples so that all accessions analyzed varied between the ellipsoid and piriform conformations. E. involucrata can be classified as a "small fruit," not only due to their reduced dimensions, but also thanks to the expression of great antioxidant capacity, the richness of phenolic compounds, such as tannins and flavonoids (Dametto 2014, Nicácio et al. 2017), the delicacy of the fruits and short shelf life, characteristics common to berries, such as blueberry, raspberry, strawberry, and other fruits included in this classification (Barbieri \& Vizzotto 2012).

The average height of the fruit was $2.4 \mathrm{~cm}$, slightly higher than the value obtained by Rodrigues et al. (2016) and Camlofski (2008) of 3.7 and $2.56 \mathrm{~cm}$, respectively. The average weight of the stone fruit in this study was $4.9 \mathrm{~g}$, higher than the value of 4.2 obtained in a survey developed in the Rio Grande do Sul (Rohrig et al. 2016) and Paraná, where the average was $4.54 \mathrm{~g}$ (Camlofski 2008). The average pitted weight of the seven fruit samples of $E$. involucrata was $3.35 \mathrm{~g}$, lower than the value found by Camlofski (2008), who obtained $6.75 \mathrm{~g}$, and close to Antonia's (2020), whose average was $3.85 \mathrm{~g}$. The pulp yield obtained was $68.36 \%$ less than $84.30 \%$ recorded for accessions in the state of São Paulo (Antonia 2020) and for accessions in Paraná (Camlofski 2008), where the yield was 76,57\%. The accession 3.D was the one with the highest pulp yield, with an average weight of $4.5 \mathrm{~g}$.

A quality parameter mentioned in the ethnobotanical survey was the acidity of fruits when destined for jelly processing. The $\mathrm{pH}$ is an important factor to achieve the ideal texture of jellies, since $\mathrm{pH}$ is linked to sugar and pectin giving the jelly-like texture, and the targeted range is between 3.2 and 3.5 (Torrezan 1998). The average pH was 3.8, slightly higher than that found by Camlofski (2008) of 3.14, and that registered for three E. involucrata plants by Schmidt (2018), which obtained values between 2.31 and 2.50 .

The total soluble solids ranged by up to 5 degrees (from 5.6 until $10.6^{\circ}$ Brix) between the accessions, and this variation can be attributed to several environmental, genetic, management factors, ripening stage, and metabolic processes. High levels of soluble solids are desirable for fresh consumption but also to industry, where higher soluble solids reduce content reduces processing costs (Gonzaga et al. 1986). The average concentration of total soluble solids was 7.30 Brix, lower than that found by Rodrigues et al. (2016), Camlofski (2008), Rohrig et al. (2016), and Antonia (2020), who obtained values within the range between $8.6^{\circ}$ and $12.7^{\circ}$, but higher than in two of the threes evaluated by Schmidt (2018) in the state of Rio Grande do Sul, which obtained 5.72 and $5.61^{\circ}$ Brix.

The ratio gives a better indication of maturity and flavor, as it takes both sugar concentration and titratable acidity into account (Pierro 2002). The average ratio was 12.04, higher than that founded by Antonia (2020), who registered a ratio of 11.42. Considering the preference for sweeter fruits, the main selection criteria pointed by all family units, this parameter can be useful to evaluate the quality of the fruits.

The average vitamin C content was $53.28 \mathrm{mg}$ of ascorbic acid in $100 \mathrm{ml}$ of juice, a relative concentration to that recorded by Lopes (2009) in three years of evaluation, which finds values of $56.59 \mathrm{mg}, 42.82 \mathrm{mg}$, and $54.32 \mathrm{mg}$. The accession with the highest concentration of ascorbic acid was D.3 with $72.47 \mathrm{mg}$ in $100 \mathrm{ml}$ of juice. The daily consumption recommended by the Brazilian National Health Surveillance Agency, according to the ordinance of January 13, 1998, is $60 \mathrm{mg}$ of vitamin C per day (BRAZIL 1998). So, E. involucrata is considered a good source of vitamin $C$ since, for the average of this study, with just $113 \mathrm{ml}$ of juice, it is possible to supply the daily need.

Even though belonging to the same region, sharing the same climate type with mild summers, soil with clayey texture presenting Latossolo Bruno as major soil substrate, and proximity of $31.7 \mathrm{~km}$ (Wrege et al. 2012), variability could be identified.

Despite the proximity of the municipalities, there are small geographic differences that can affect the chemical and morphological attributes of $E$. involucrata. Curitibanos has an altitude of $1016 \mathrm{~m}$, an average annual temperature of $16,5^{\circ} \mathrm{C}$, and an annual rainfall average of $1479,7 \mathrm{~mm}$ (Wrege et al., 2012). In turn, Frei Rogério has an altitude of $950 \mathrm{~m}$, an annual temperature average of $16,4^{\circ} \mathrm{C}$, annual rainfall average of $1600 \mathrm{~mm}$ (Santa Catarina 1994). 
Furthermore, the accessions come from varied locations and may respond in different ways to environmental conditions, such as relief, nutritional soil conditions, and microclimate.

Among the seven accessions evaluated, accessions 3.D, 4.MI, 5.MII, and 6.G seem to meet best the selection criteria for $E$. involucrata, defined by the participants in the study. These accessions present greater fruit size and height and good values for the concentration of soluble solids, the highlight being the 6.G which presented the highest SS/AT ratio.

The genetic variability exiting in the same region aggregate potential to select materials that fulfill the local needs and preferences, even in the face of several divergent selection criteria (as in this study), this variability allows the development of cultivars with different aptitudes and purposes. The development of cultivars is an approach that contributes to extending the value of neglected species is increasing the use of genetic diversity (Cowlling et al. 1998). Historically, plant breeding programs have excluded the rural, traditional, and local communities from the process of crop development, but nowadays demand for a systemic approach is emerging in the scientific world. The systematic basis implies that is not possible to understand the reality as individualized parts since a system is formed by mutually interdependent components (Gomes et al. 2014), in a way where the scientific development must also consider the social component once there is no science excluded from its environment (Capra 1997, Gomes \& Medeiros 2009, Lacey 2012).

Participatory genetic breeding can be considered a systematic alternative from traditional breeding, where popular and traditional knowledge is recognized (Gomes et al. 2014, Lacey 2012). In this method, the decision-making processes and establishment of the selection parameters are carried out jointly, valuing the important role of traditional knowledge (Eizaguirre \& Iwanaga 1995, Soglio 2017). It includes the family units of the species in decision-making and the establishment of selection parameters for the species, aiming to develop cultivars that meet the local needs as long as people who daily manage and conserve these resources are more qualified to establish criteria and select (Soglio 2017).

Considering the scenario addressed in this study, where a predominant bond with $E$. involucrata was perceived, plus the belief in the potential for sale, and the interest in management and yield aspects aiming income generation, it is considered that the development of cultivars of E. involucrata via participatory approach could be a perspective to achieve both: income generation and conservation of the species through its use.

The species is still marginalized, and the characterization of the existing genetic diversity is needed, as well as the determination of criteria to indicate the harvest point, and development of agricultural management. The physicalchemical evaluations in this study showed a portion of variability available, but to access the real potential of genetic diversity it is necessary to increase the sampling.

This study provides an initial panorama of the knowledge associated with the E. involucrata, however, the occurrence area of the species is vast, and the different contexts may hold a source of diversified unknown information. Brazil has continental proportions, but even in the state of Santa Catarina is observable the mosaic of ethnicity, cultures, and realities. In this sense we highlight the necessity of fulfilling the gaps, not only involved with agricultural aspects but also with the related knowledge since local and traditional knowledge can provide key ideas for conservation strategies, and also contribute to developing products and services.

\section{Conclusions}

The family units interviewed share a cultural relationship with Eugenia involucrata, which is mostly manifested through the family bond, or childhood ties. 37 of 50 plants addressed in the ethnobotanical survey did not occur naturally on the landscape but were planted by the family units, which supports that there is an effort to conserve the species and their associated sociocultural relationships. The bond with the $E$. involucrata has perpetuated generation after generation through the continued use of the species. There was diversity among the seven accessions evaluated for the parameters of height, diameter, $\mathrm{pH}$, vitamin $\mathrm{C}$, titratable acid, and ratio. The main selection criteria were preference for sweeter fruit, darker fruit, and larger fruit. The accessions 3.D, 4.MI, 5.MII and 6.G can be considered the most promising, as they best meet the preferred traits pointed out by family units, showing greater fruit height and size, and high values of soluble solids. 


\section{Declarations}

List of abbreviations: Not applicable.

Availability of data and material: Data sets were deposited in the public repository of the Federal University of Santa Catarina (Campus Curitibanos), under registration numbers CTBS4028 and CTBS3943.

Ethics approval and consent to participate: The study was submitted to the Ethics Committee of the Federal University of Santa Catarina (UFSC) and was approved under the registration number: CAAE: 54636616.3.00 0.0121. The research proposal was presented to each participating family unit, and an informed consent form was delivered, which marked the possibility of giving up at any time during the research without any risk or harm.

Funding: There was no funding received from any institution.

Competing interests: The authors do not have any competing interests.

Authors' contributions: Julia Goetten Wagner did the preliminary work, semi-structured interviews, plant collection, laboratory evaluations, drafted the manuscript, and revision of the manuscript. Karine Louise dos Santos did the field survey, defined the ethnobotany methodology, collected plant material, reviewed the literature, and revision of the manuscript. Dilma Budziak assisted in laboratory evaluations, did the verification and revision of the manuscript. Rosa Lía Barbieri analyzed data sources and literature related to the biological sciences and revised the manuscript.

\section{Literature cited}

Albuquerque UP, Araújo TAS, Ramos MA, Nascimento VT, Lucena RFP, Monteiro JM, Alencar NA, Araújo EL. 2008. How ethnobotany can aid biodiversity conservation: reflections on investigations in the semi-arid region of $\mathrm{NE}$ Brazil. Biodiversity and conservation 18:127-150.

Alho CJR. 2012. Importância da biodiversidade para a saúde humana: uma perspectiva ecológica. Estudos avançados., São Paulo 26(74).

Antonia, BD. 2020. Qualidade pós-colheita de cerejeja-do-rio-grande (Eugenia involucrata DC): caracterização de acessos e estádios de maturação. Dissertação de Mestrado em Ciências. 54p.

Association of analytical chemists- AOAC. 1997.Official methods of analysis of the AOAC Washington, EUA.

Barbieri RL. 2003. Conservação e Uso de Recursos Genéticos. In Genética e Evolução Vegeta. Organized by LB Freitas, F Bered. Editora da UFRGS, Porto Alegre, Brasil, Pp 403-413.

Barbieri RL, Vizzotto M. 2012. Pequenas frutas ou frutas vermelhas. Pequenas frutas: tecnologias de produção.. Informe Agropecuário 33 (268): 7-10.

Bailey KD. 1982. Methods of social research. Second Edition. Free Press, New York, EUA.

Bergamin RS, Bastazini VAG, Vélez-Martin E, Debastiani V, Zanini KJ, Loyola R, Müller SC. 2017. Linking beta diversity patterns to protected areas: lessons from Brazilian Atlantic Rainforest. Biodiversity and Conservation 26(7):15571568.

Berkes F, Folke C, Gagdil M. 1994. Traditional Ecological Knowledge, Biodiversity, Resilience and Sustainability. In: Biodiversity Conservation. Ecology, Economy \& Environment. Edited by CA Perrings, KG Mäler, C Folke, CS Holling, BO Jansson 4:281-299.

Bernard HR. 1994. Research methods in anthropology. Analysis of qualitative data. Altamira Press, Walnut Creek, EUA.

Buianain AM, Favareto A, Contini E, Chaves FT, Henz GP, Garcia JR, Damiani O, Vieira PA, Grundling RDP, Nogueira VGC. 2020. Desafios para agricultura nos biomas brasileiros. Embrapa, Brasília, 69 p.

Bussmann RW. 2002. Ethnobotany and Biodiversity Conservation. In Modern Trends in Applied Terristrial Ecology. Edited by RS Ambasht, Ambasht NK. Springer, Boston, EUA.

Butzke A, Pontalti S. 2012. Os recursos naturais e o homem: o direito ao meio ambiente ecologicamente equilibrado frente à responsabilidade solidária. Educs, Caxias do Sul, Brasil.

Byg A, Baslev H. 2001. Diversity and use of palms in Zahamena, eastern Madagascar. Biodiversity and Conservation 10:951-970. 
Camlofski AMO. 2008. Caracterização do fruto de cerejeira (Eugenia involucrata) visando seu aproveitamento tecnológico. Dissertação de Mestrado em Ciência e Tecnologia de Alimentos. Universidade Estadual de Ponta Grossa. 102p.

Capra F. 1982. O ponto de mutação: a ciência, a sociedade e a cultura emergente. Cultrix São Paulo, Brasil.

Carvalho PER. 2009. Cerejeira - Eugenia involucrata. Comunicado Técnico 24 -Embrapa Florestas, Colombo, Brasil.

Castro CM, Devide ACP. 2015. Resgate de conhecimentos tradicionais: produção e consumo de plantas não convencionais. Pesquisa \& Tecnologia 12(1).

Clement CR, Casas A, Parra-Rondinel FA, Levis C, Peroni N, Hanazaki N, Cortés-Zárraga L, Rangel-Landa S, Alves RP, Ferreira MJ, Cassino MF, Coelho SD, Cruz-Soriano A, Pancorbo-Oliveira M, Blancas J, Martínez-Ballesté A, Lemes G, Lotero-Velásques E, Bertin VM, Mazzochini GG. 2021. Disentangling domestication from food production systems in the Neotropics. Quaternary 4(4).

Cowling WA, Bevan JB, Tapia ME. 1998. Lupin. Lupinus L. Promoting the conservation and use of underutilized and neglected crops. Institute of Plant Genetics and Crop Plant Research, Gaterslesben/International Plant Genetic Resources Institute, Rome, Italy, 34p.

Cruz CD. 2006. Programa Genes: Biometria. Editora UFV, Viçosa.

Cruz MP, Neves CSVJ, Carvalho D U, Colombo R C, Leite RP, Tazima ZH. 2019. "Navelina" sweet orange trees in five rootstocks in Northern Parana state, Brazil. Revista Brasileira de Fruticultura 41(3).

Dametto AC. 2014. Estudo químico e avaliação da atividade biológica de Eugenia brasiliensis e Eugenia involucrata (Myrtaceae). Tese de Doutorado em Química. Universidade Estadual Paulista Júlio de Mesquita Filho. 169 p.

Degenhardt J, Frazon RC, Costa RR. 2007. Cerejeira-do-mato (Eugenia involucrata). Documentos 211 - Embrapa Clima Temperado, Pelotas, Brasil.

Descola PA. 1999. A selvageria oculta. In: A outra margem do ocidente. Edited by A Novaes. Companhia das Letras, São Paulo. Brasil Pp. 107-124.

Díaz S, Settele J, Brondízio E. 2019. Summary for policymakers of the global assessment report on biodiversity and ecosystem services of Intergovernamental Science-Policy platform on Biodiversity and Ecosystem Services. Disponível em <https://www.ipbes.net/sites/default/files/downloads/spm_unedited_advance_for_posting_htn.pd> acesso em 23 de março de 2020.

Eyzaguirre P, Iwanaga M. 1995. Farmer's contribution to maintaining genetic diversity in crops, and its role within the total genetic resources system. Participatory Plant Breeding. Wageningen - Netherlands: Internacional Plant Genetical Resources Institute p. 3-14.

Fortaleza JM, Peixoto JR, Junqueira NTV, Oliveira, AT, Rangel LEP. 2005. Características físicas e químicas em nove genótipos de maracujá-azedo cultivado sob três níveis de adubação potássica. Revista Brasileira de Fruticultura 27(1).

Franco LMPB. 2005. Análise de conteúdo. Liber Livro, Brasília, 79 p.

Girardelo JR, Munari EL, Dallorsoleta JCS, Cechinel G, Goetten ALF, Sales RL, Reginatto FH, Chaves VC, Smaniotto FA, Somacal S, Emanuelli T, Benech JC, Soldi C, Winter E, Conterato GMM. 2020. Bioactive compounds, antioxidante capacity and antitumoral activity of ethanolic extracts from fruits and seeds of Eugenia involucrata DC. Food Research International 137.

Gonzaga Neto L, Abramof L, Bezerra JEF, Dantas AP, Silva HM, Souza MM. 1986. Seleção de cultivares de goiabeira para fins industriais, na região do Vale do Rio Moxotó. Revista Brasileira de Furiticultura 8:55-61.

Gonçalves A, Guazelli MJ. 2014. Agrofloresta e óleos essenciais. Centro ecológico.

Hansen DS, Silva SA, Fonseca AAO, Hansen OAS, França NA. 2008. Caracterização química de frutos de jenipapeiros nativos do Recôncavo Baiano visando ao consumo e industrialização. 2008. Revista Brasileira de Fruticultura 30(4).

Hasenack H, Weber E. (org.) 2010. Base cartográfica vetorial contínua do Rio Grande do Sul - escala 1:50.000. Porto Alegre: UFRGS/Centro de Ecologia. DVD-ROM (Série Geoprocessamento, 3). 
Hickey GM, Pouliot M, Smith-hall C, Wunder S, Nielsen MR. 2016. Quantifying the economic contribution of wild food harvests to rural livelihoods: A global-comparative analysis. Food Policy 62:122-132.

Hunter D, Borelli T, Beltrame DMO, Oliveira CNS, Coradin L, Wasike VW, Wasilwa L, Mwai J, Manjella A, Samarasinghe GWL, Madhujith T, Nadeeshani HVH, Tan A, Ay ST, Güzelsoy N, Lauridsen N, Gee E, Tartanac F. 2019. The potential of neglected and underutilized species for improving diets and nutrition. Planta 250:709-729.

IBGE - Instituto Brasileiro de Geografia e Estatística. 2017. Santa Catarina - Curitibanos. Disponível em <https://cidades.ibge.gov.br/brasil/sc/curitibanos> acesso em 13 lout 2017.

IBGE - Instituto Brasileiro de Geografia e Estatística. 2019. Malhas territoriais. https://www.ibge.gov.br/geociencias/organizacao-do-territorio/malhas-territoriais.html. Acessed on: 2021-11-15.

INPE - INSTITUTO NACIONAL DE PESQUISAS ESPECIAIS. 2021. SOS Mata Atlântica e INPE lançam novos dados do Atlas do bioma. Disponível em: <http://www.inpe.br/noticias/noticia.php?Cod_Noticia=5115\#: :text=O\%20Atlas\%20da\%20Mata\%20Atl\%C3\%A2 ntica,da\%20\%C3\%A1rea\%20original\%20do\%20bioma> Acesso em 10 mar. 2021.

Johnson MC, Poulin M, Graham M. 2007. Rumo a uma abordagem integrada da conservação e uso sustentável da biodiversidade: Lições aprendidas a partir do projeto da biodiversidade do rio Rideau. Ambiente e Sociedade 10(1):58-86.

Joly CA, Haddad CFB, Verdade LM, Oliveira MC, Bolzani VS, Berlinck RGS. 2011. Diagnóstico da pesquisa em biodiversidade no Brasil. Revista USP 89.

Jonsson M. 2011. Perda da biodiversidade e funcionamento dos ecossistemas. Ecologia Info 30.

Kinupp VF. 2008. Plantas alimentícias não convencionais da região metropolitana de Porto Alegre - RS. Revista Brasileira de Agroecologia 3(3):53-54.

Lacey H. 2012. Pluralismo metodológico, incomensurabilidade e o status científico do saber tradicional. Scientia e Studia 10(3).

Lima RS, Ferreira Neto JA, Farias RCP. 2015. Alimentação, comida e saúde: O exercício da comensalidade. Demetra: Alimentação, Nutrição e Saúde 10 (3):507-522.

Lisbôa G, N, Kinupp VF, Barros, IBI. 2011. Eugenia involucrata Cerejeira-do-rio-grande. In: Espécies Nativas da Flora Brasileira de Valor Econômico Atual ou Potencial: Plantas para o Futuro - Região Sul. Edited by L Coradin, A Siminski, A Reis. MMA, Brasília, Brasil, Pp 163-168.

Lorenzi H. 2002. Árvores Brasileiras: Manual de identificação e cultivo de plantas arbóreas nativas do Brasil. Instituto Plantarum, Nova Odessa, Brasil.

Louv R. 2009. Do our kids have Nature-Deficit Disorder? Educational Leadership 67(4):24-30.

Milach EM, Louzada MC, Abrão RK. 2016. O espaço verde nas escolas de educação infantil Revista Cippus 16(1).

Minayo MCS. 2006. O desafio do conhecimento: Pesquisa qualitativa em saúde. Hucitec, São Paulo, Brasil.

Mintz SW. 2001. Comida e antropologia: uma breve revisão. Revista Brasileira de Ciências Sociais 16 (47):31- 41.

Moretto SP. 2017. Meio ambiente e sociedade: as transformações na paisagem do Oeste Catarinense, na segunda metade do século XX. História Revista 2 (6):711-728.

Negi VS, Pathak R, Sekar C. Rawal, SR.; Bhatt I D, Nandi SK, Dhyani P.P. 2017. Traditional knowledge and biodiversity conservation: a case study from Byans Valley in Kailash Sacred Landscape, India. Journal of Environmental Planning and Management 61(10):1722-1743.

Netting RM. 1993. Smallholders, Householders: farm families and the ecology of intensive, sustainable agriculture. Stanford University Press, Stanford, EUA.

Nicácio AE, Rotta EM.; Boeing JS, Barizão EO, Kimura E. 2017. Antioxidant activity and determination of phenolic compounds from Eugenia involucrata DC. Fruits by UHPLC-MS/MS. Food Analytical Methods 10:2718-2728.

Oliveira LC, Oliveira ATF, Eisenlohr PV. 2020. Emerging hotspots of tree richness in Brazil. Acta Botanica Brasilica 34(1):117-134. 
Oliveira MA. 2016a. Economia e população em Curitibanos/SC: o que a história da nucleação escolar diz acerca da relação trabalho/educação no mundo rural. ANPED Sul: Reunião científica regional da ANPED. Curitiba, Brasil.

Oliveira MA. 2016b. Rural world (economy, labor and migrations) in the Serra Catarinense/Brazil: elements for discussion of the centrality of agricultural work in rural areas in the context of its current productive restructuration. Jornal de Políticas Internacionais, 10(20):106-117.

Oliveira U, Soares-Filho BS, Paglia AP, Brescovit AD, Carvalho CJB, Silva DP, Rezende DT, Leite FSF, Batista JAN, Barbosa JPPP, Stehmann J R, Ascher JS, Vasconcelos MF, Marco P, Löwenberg-Neto P, Ferro VG, Santos AJ. 2018. Biodiversity conservation gaps in the Brazilian protected areas. Scientific Reports 7:9141.

Padulosi S, Eyzaquirre P, Hodgkin T. 1999. Challenges and strategies in promoting conservation use of neglected and underutilized crop species. In Perspectives on new crops and new uses, ASHS Press - Alexandria, VA, EUA, pp. 140-145.

Palonen P, Weber C. 2019. Fruit color stability, anthocyanins contents, and shelf life were not correlated with ethylene production rate in five primocane raspberry s. Scientia Horticulturae 247:9-16.

Penso GA, Santos CEM, Bruckner CH, Costa J CF, Citadin I. 2018. Consumo, preferências e hábitos de consumidores de pêssegos e nectarinas. Revista Brasileira de Fruticultura 40(3).

Pierro A. Gosto bom. 2002. Cultivar - Hortaliças e frutas 14:10-12.

Rego GM, Lavoranti OJ, Assumpção Neto A. 2006. Floração e frutificação da cerejeira-do-mato em áreas fragmentadas da floresta ombrófila mista no município de Colombo-PR. Circular Técnica 129 - Embrapa Florestas, Colombo, Brasil.

Ribeiro RC. 2017. Aspectos históricos, demográficos, morfológicos e genéticos de populações de Butia eriospatha (Martius ex Drude) Beccari (Arecaceae) em paisagens contrastantes no planalto serrano de Santa Catarina. Dissertação de Mestrado em Recursos Genéticos Vegetais. Universidade Federal de Santa Catarina. 203p.

Santa Catarina - Secretaria de Estado da Agricultura e Abastecimento. 1994. Manual de uso, manejo e conservação do solo e da água. Epagri - Florianópolis, 2. ed.

Sardi JCO, Freires IA, Lazarini JG, Infante J, Alencar SM, Rosalen PL. 2017. Unexplored endemic fruits species from Brazil: Antibiofilm properties, insights into mode of action, and systemic toxicity of four Eugenia spp. Microbial Pathogenesis. 105:280-287.

Schiassi MCEV, Souza VR, Lago AMT, Campos LG, Queiroz F. 2018. Fruits from de brazilian cerrado region: Pshychochemical characterization, bioactive compounds, antioxidant activities, and sensory evaluation. Food Chemistry 245(15):305-311.

Schmidt H. 2018. Caracterização físico-química, nutricional e de compostos bioativos de sete espécies da família Myrtaceae nativas da região sul do Brasil. Dissertação (Mestrado em Ciência e Tecnologia de Alimentos) Universidade Federal do Rio Grande do Sul, $163 \mathrm{p}$

Soglio FKD. 2017. Princípios e aplicações da pesquisa participativa em agroecologia. Redes 22(2):116-136.

Stella A, Kageyama P. 2006. Agrobiodiversidade e diversidade cultural. Brasília: MMA.

Tabarelli M, Pinto LP, Silva JMC, Hirota MM, Bedê LC. 2005. Desafios e oportunidades para a conservação da biodiversidade na mata atlântica brasileira. Megadiversidade. Conservação Internacional Brasil 1(1):133-138.

Toledo VM. La diversidad biológica de México. 1988. Ciência y Desarollo 97:79-88.

Torrezan R. 1998. Manual para fabricação de geleias de frutas em escala comercial. Embrapa, Rio de Janeiro -RJ.

Tunnicliffe S. 2001. Talking about plants - comments of primary school groups looking at plants as exhibits in a botanical garden. Journal of Biological Education 36:27-34

UNESCO. 2003. Cultural diversity and biodiversity for sustainable development. In: World Summiton Sustainable Development. Johannesburg, South Africa. 
Vechi G, Campos A, Rosa RL, Capistrano K, Zermiani T, Buzzi FC, Andrade SF, Cechinel Filho V. 2018. Analyses of chemical composition and gastroprotective and antinociceptive properties of Eugenia involucrata DC leaves. Journal of Applied Pharmaceutical Science 8(4):79-83.

Viertler RB. 2002. Métodos antropológicos como ferramentas para estudos em etnobiologia e etnoecologia. In: Métodos de coletas e análise de dados em etnobiologia, etnoecologia e disciplinas correlatas. UNESP, Rio Claro, Brasil, Pp. 11-29.

Vilela GF, Bentes MPM, Oliveira YMM, Marques DKS, Silva JCB. 2018. Vida terrestre: Contribuições da Embrapa. Embrapa, Brasília - DF, 2018

Volpato CA, Donazzolo J; Nodari RO. 2011. Melhoramento Participativo da Goiabeira-Serrana: Uma Parceria que dá Frutas. UFSC/CCA, Florianópolis, Brasil.

Watson JEM, Evans T, Venter O, Williams B, Tulloch A, Stewart C, Thompson I, Ray JC, Murray K, Salazar A, McAlpine C, Potapov P, Walston J, Robinson JG, Painter M, Wilkie D, Filardi C, Laurence WF, Houhghton RA, Maxwell S, Grantham H, Samper C, Wang S, Laestadius L, Runting RK, Silva-Chávez GA, Ervin J, Lindenmayer D. 2018. The exceptional value of intact forest ecosystems. Nature Ecology \& Evolution 2:599-610.

We are social, HootsuiteTM. 2017. Digital in 2017: A global overview. Disponível em: <https://wearesocial.com/special-reports/digital-in-2017-global-overview>. Acesso em 02/11/2017.

Wrege MS, Steinmetz S, Reisser Júnior C, Almeida IR (eds). 2012. Atlas climático da região Sul do Brasil - Estados do Paraná, Santa Catarina e Rio Grande do Sul. Embrapa, Brasília - DF, 2. ed. 
